\title{
Analysis of Maize Processing in Ughelli North Local Government Area of Delta State, Nigeria
}

\author{
Ovharhe, O. J. ( Corresponding author) \\ Department of Agricultural Economics and Extension, Delta State University, Asaba Campus, \\ Asaba, Nigeria. Tel: 08080568889
}

Received: January 9, 2015

Accepted: March 37, 2016 Published: March 30, 2016

doi:10.5296/jas.v4i2.9226

URL: http://dx.doi.org/10.5296/jas.v4i2.9226

\begin{abstract}
This article was centered on the analysis of maize processing in Ughelli-North Local Government Area of Delta State, Nigeria. The specific objectives of the study were to identify the socio-economic characteristics of farmers involved in maize processing, analyze the methods of maize processing, ascertain the level of awareness of improved technology in maize processing and identify the various products of maize in the area. One Hundred questionnaires were administered to the respondents. The data collected were analyzed using simple statistical tools such as frequency distribution, percentages and regression model. Some findings from the analysis revealed that female $(91 \%)$ were more into maize processing than male $(9 \%)$. The research also revealed that $91 \%$ of the respondents used traditional processing method and their level awareness to improve maize varieties and product is $65 \%$. The level of access to modern technology is low. The result from the analysis showed that $\mathrm{R}=0.702, \mathrm{R}^{2}=0.690$ at $\mathrm{P}=0.034$. This showed that some of the socioeconomic characteristics of the farmers did affect maize processing. Necessary recommendations included males particularly youth should be encouraged to go into maize processing and should not be regarded as females' jobs, all age categories and farmers with no formal education should be encouraged to go into maize processing, more awareness on improved varieties should be brought to farmers and credit facilities should be made available to farmers and increase in accessibility to modern maize processing techniques.
\end{abstract}

Keywords: Maize, processing, techniques, farmers.

\section{Background Information}

Maize (Zea mays L. Poaceae) is the most important cereal in the world after wheat and rice with regards to cultivation areas and total output. (Purseglove, 1992; Osagie and Eka. 1998). The name maize is derived from the South America India Arawak-carib word mahis. It is known as Indian corn or corn in America (Purseglove, 1992). It was introduced into Nigeria 
probably in the 16th century by the Portuguese. In Nigeria, maize is known and called by different vernacular names depending on the ethnic groups like 'Ogbado' 'Igbado' or 'Dawar Masara' (Hausa); 'Ogbado' or 'Oka' (Ibo); 'Apaapa' (Ibira); Oka (Benin, Esan and Urhobo).

Agriculture is an important sector of the Nigerian economy, a large percentage of working population of the country is employed in some form of agricultural pursuit or the other (Anyanwu, et $a l$ ).The overall agricultural situation deteriorating, creating wide gap between demand and supply for food. Revenue from agricultural sector dwindles and the government is faced with mounting food import bills, thus putting considerable stress on Nigeria foreign exchange earnings. This is due to the fact that the nation's agriculture has always been dominated by small holder farmers who represent a substantial proportion of total farming population and produce over $90 \%$ of the total agricultural output in the country (Ajibenfun, 2002).

One of the rural women's greatest needs is time-saving technologies which will enlighten their excessive workload and reduce the length of their working day; thereby increasing their productivity. As women are the back bones of agricultural sector accounting for 60 to $80 \%$ of agricultural labour and being responsible for $80 \%$ of food production. (Ngur, 1987; Kabeer, 1994; Ingawa, 1999; and Mgbada, 2000). It is important to try to close the gap between the actual and potential productivity levels of their on-farms labour. The bridging of the actual potential productivity gap represents one of the most effective means of promoting agricultural productivity and enhancing the overall economic developing countries like Nigeria Agricultural technologies which require increase in labour time or are not adapted to women's daily and seasonal time schedules are likely to be adopted. In addition to constraints on their own labour time, women cannot call on the labour of other household members in the way the men can (Malena, 1994). An increase in women's resources may therefore bring about more direct and immediate developmental effects (Gabriel, 1991).

The absence of qualitative and quantitative data on gender-labour productivity has contributed to the inadequate and support for women's role in agricultural production and development. This lack of data also prevented women from realizing their full potential. The contribution of women to agricultural development should be maximized through full integration of women into agricultural and rural development programmes for the purpose of efficiency and sustainability. The recognition and promotion of women's role in agriculture requires examining the productivity of the labour on farm, in order to clarify further on the benefits of women's participation in agriculture.

In view of the fact that women play major roles in rural development, it becomes necessary that their activities are studied, more so, where women make up to more than one and half of the rural population (Eboh, E.C., Okoye U. C. and Ayichi, D.1995). The recognition of the role played by women in agriculture is fundamental to agricultural development. More reportedly, recognizing and supporting this role is crucial for development of women and fulfillment of their economic potential.

\subsection{Statement of the problem}

Maize has been of tremendous importance in Nigerian agricultural economy. It is the countries third most important cereal following sorghum and millet (Ojo, 2000). The task of feeding the nation adequately constitutes an increasing challenge requiring the co-ordinate 


\section{Macrothink}

Journal of Agricultural Studies

ISSN 2166-0379

2016, Vol. 4, No. 2

interaction of food producers, transporters, marketers and myriad sellers (Ojo, 2000). Despite the importance of maize to Nigerian economy, a lot of issues plaque this sector.

The main essence of the study was to find answers to the following research problems: What are the socio-economic characteristics of the women involved in maize processing? Are the women applying right method of maize processing? Can the current improved technologies of maize processing be sustained, and what are the various products of maize in the area?

\subsection{Objectives}

The main objective was to study the analysis of women in maize processing in Ughelli-North Local Government Area of Delta State, Nigeria. The specific objectives to study were to:

a) Identify the socio-economic characteristics of women involved in maize processing,

b) Analyze the methods of maize processing,

c) Ascertain the level of awareness of improved technology in maize processing and

d) Identify various products of maize in the area.

\subsection{Hypothesis}

The following will guide the research;

Ho: Socio-economic characteristics do not significantly affect maize processing.

\section{Research Methodology}

\subsection{The Study Area}

The Study area of the research work was Ughelli-North Local Government Area of Delta State, Nigeria. This area was chosen for the study due to high level of farming activities by women. It is one of the twenty-five Local Government areas in Delta State. It has it's headquarter in Ughelli.

\subsection{Population Sampling Techniques and Sample Size}

A two-stage random Sampling procedure was used in the selection of the respondents. First stage, simple random sampling techniques was used to select four communities: Ugono, Ewreni, Agbarho, Ughelli out of the seven clans. Thereafter, a list of the entire household involved in maize processing will be drawn with the assistance of the community leaders and extension agent covering the communities. In the clans, the list will constitute the sampling frame for the study. From the frame total of 25 respondents (the sample size for the study) will be selected on the basis of proportionate random sampling to get a sample size of one hundred respondents. 


\section{1) Macrothink}

Table 1. Selected clans, communities and respondents for the study

\begin{tabular}{ccc}
\hline Clan & Selected Communities & No. of Respondents \\
\hline Orogun & Ugono & 25 \\
Ughweru & & \\
Ewreni & Ewreni & 25 \\
Agbarha & & \\
Otor-ogor & Agbarho & 25 \\
Ughelli & Ughelli & 25 \\
Agbarho & & 100 \\
TOTAL & 4 &
\end{tabular}

Source: Field Survey, 2012

\section{Method for Data Collection}

Data for this study was collected from primary sources. The primary data will be collected with the use of structured questionnaires, which was administered to the 100 respondents.

\subsection{Method of Data Analysis}

Data collected in the course of study was analyzed by use of descriptive and inferential statistics. Objectives 2, 3, and 4 were achieved using statistical tools such as percentage and frequency counts, objective 2 was achieved using dichotomous scale (yes or no). Objective 3 was achieved, using a four type Likert scale ranging from very high (4), high (3), low (2) to very low (1), the cut off is 2.0. Above 2.0 is important while below 2.0 is deficient. Objective 4 was achieved using dichotomous scale (yes or no). A ranking produce was used-to identify the position of the various mean values.

The hypothesis was analyzed using Regression analysis.

$\log Y=\log a+b_{1} \log X_{1}+b_{2} \log X_{2}+b_{3} \log X_{3}+b_{4} \log X_{4}+\log e$

$\mathrm{Y}-\mathrm{a}+\mathrm{b}_{1} \mathrm{X}_{1}+\mathrm{b}_{2} \mathrm{X}_{2}+\mathrm{b}_{3} \mathrm{X}_{3}+\mathrm{b}_{4} \mathrm{X}_{4}+\mathrm{b}_{5} \mathrm{X}_{5}+\mathrm{e}$

Where

$\mathrm{Y}=$ productivity (in $\mathrm{kg} / \mathrm{ha}$ per annum)

$\mathrm{X}_{\mathrm{I}}=$ Age of respondent (in years)

$\mathrm{X}_{2}=$ Quality of raw maize grains processed (bags $/ \mathrm{kg}$ )

$\mathrm{X}_{3}=$ Household size (in number)

$\mathrm{X}_{4}=$ Credit (Naira)

$\mathrm{X}_{5}=$ processing methods (Dummy: traditional 1 and 0 for modern)

$\mathrm{e}=$ Error term . 


\section{Mll Macrothink}

\section{Results and Discussion}

\subsection{Socio-economic characteristics of farmers}

Results in Table 2 showed that the age of the respondents were under the following years: 20(3\%), 2130 (19\%), 31-40(46\%) and over 50(32\%). These results showed that majority of the farmers were between 31-40yrs and above, $91 \%$ of the respondents were female and $9 \%$ male. This result indicated that female dominated or participated more in agricultural production and processing, this result agrees with (FAO 2007b) that female are more into processing of maize, wheat and rice. $58 \%$ of the farmers were married, $15 \%$ were single, $15 \%$ were widowed, and widower $3 \%$ and $9 \%$ were divorced. This result showed that more of the farmers were married. It was revealed that family size of $2-5(50 \%) 5-10(34 \%), 10-15(11 \%)$ and $15-20(5 \%)$ above $20(0)$. This result showed that most family size were 2-5 (50\%). and On education, 5-10 20\% of the respondents had primary education, $61 \%$ had secondary education, $4 \%$ tertiary education and $15 \%$ had none. This result showed that majority of the farmers had secondary education. Maize buyers' quantity of maize quantity bought in $\mathrm{kg} 50-100 \mathrm{~kg}(8 \%), 100-150 \mathrm{~kg}$ (23\%), $150-200 \mathrm{~kg}(17 \%), 200-250 \mathrm{~kg}(1 \%)$ above $250 \mathrm{~kg}(2 \%)$. This result showed that majority of the farmers buy $100-150 \mathrm{~kg}$ of maize and they are usually small scale farmers. Farm sizes of the respondents were as follows: less than 0.5 ha $(3 \%), 0.5-1$ ha $(15 \%)$, $1-1.5 \mathrm{ha}(16 \%), 1.5-2 \mathrm{ha}(11 \%)$ and above $2 \mathrm{ha}(1 \%)$. This result shows that majority of the farmer possessed farm size of 1-1.5ha for maize production. Annual income of farmers into maize processing were less tha 100,000 (24\%), 100,000-200,000 (38\%), 200,000-300,000 (23\%), 400,000-500,000 (7\%), above 500,000(8\%). This result showed that most maize farmers' annual income ranges from 100,000-200,000 which is very low. Rural women who are members of co-operatives; Yes (41\%) and No (59\%). This shows that majority of the female maize processors are not member of co-operatives.

Table 2. Socio economic characteristics (Objective 1)

\begin{tabular}{lcc}
\hline \multicolumn{1}{c}{ Characteristics } & Frequency & Percentage (\%) \\
\hline Age & 19 & 19.0 \\
$21-30$ & 46 & 46.0 \\
$31-40$ & 32 & 32.0 \\
Over 50 & & \\
Gender & 91 & 91.0 \\
Female & 8 & 8.0 \\
Male & & \\
Marital Status & 58 & 58.0 \\
Married & 15 & 15.0 \\
Single & 15 & 15.0 \\
Widowed & 3 & 3.0 \\
Widower & 9 & 9.0 \\
Divorced & & \\
Family Size & &
\end{tabular}


5-10

$10-15$

\section{Educational Level}

Primary

Secondary

Tertiary

4.0

None

15.0

Quantity of Maize bought

$50-100 \mathrm{~kg}$

$100-150 \mathrm{~kg}$

$150-200 \mathrm{~kg}$

200-250kg

Above 250kg

1.0

\section{Farm Size}

Less than 0.5 ha

0.5-1ha

1-1.5ha

1.5 - 2ha

11.0

Above 2ha

\section{Annual Income}

Less than 100,000

$100,000-200,000$

$200,000-300,000$

23.0

$400,000-500,000$

Above 500,000

\section{Women Cooperative} members

Yes

59.0

Source: Field Survey, 2012

\subsection{Method of Maize Processing}

Results in Table 3 showed that $21 \%$ of farmers were exposed to modern facilities and $79 \%$ were not exposed. Majority of the farmer used traditional methods $(91 \%)$ and $9 \%$ did not use this method. A portion of $79 \%$ of the farmers used wet milling processing method while $21 \%$ were not involved in this process. This result shows that few of the farmers are involved with wet milling while majority of them are not. Again, 5\% of the farmers used dry milling processing methods and $95 \%$ of farmers were aware of dry milling methods. This result shows that farmers do not use dry milling method. $98 \%$ of the farmers use shelving methods after processing while $2 \%$ of them do not use shelfing method after processing. Training programme organized by extension workers are not 
materialized yes $(9 \%)$ and No $(91 \%)$. This result showed that rural farmers are neglected by extension workers, this result agrees with (Jiggins, Samantha and Olawoye 1997) that women lack extension services.

Table 3. Method of maize processing (Objective 2)

\begin{tabular}{lcc}
\hline \multicolumn{1}{c}{ Processing methods } & Frequency & $\begin{array}{c}\text { Percentage of } \\
\text { respondent }\end{array}$ \\
\hline Modern Processing Method & 21 & 21 \\
Yes & 79 & 79 \\
No & & \\
Traditional Processing Method & 91 & 91 \\
Yes & 9 & 9 \\
No & 9 & 9 \\
Ownership of the processing equipment & 91 & 91 \\
Yes & & 79 \\
No & 79 & 21 \\
Wet Milling processing method & 21 & 5 \\
Yes & & 5 \\
No & 5 & 98 \\
Yes Milling processing method & 95 & 2 \\
No & & \\
Shelfing processing method & 98 & 9 \\
Yes & 2 & 91 \\
No & & \\
Training Prog. Organized by extension worker & 9 & 91 \\
Yes & & \\
No & & \\
\hline
\end{tabular}

Source: Field Survey, 2012

\subsection{Awareness to improved technology}

Results in Table 4 showed how often farmers get access to modem technology as follows: low (24\%), average (28\%), high (3\%) and none $(45 \%)$. level of awareness of farmers to improved maize varieties and products. Low (17\%), average (65\%), high $(12 \%)$ and none $(8 \%)$. This result shows that the farmers are aware of improved maize varieties. Level of availability of improved maize varieties for processing. Low (22\%), average $(57 \%)$, high $(14 \%)$ and none $7 \%$. This result shows that improved maize varieties are readily available to farmers. Knowledge of processing techniques in agidi: Low (16\%), average (53\%), high (28\%), none (3\%). This result shows that they have knowledge of processing technique in agidi. Knowledge of processing technique in pap: low $(7 \%)$, average $(58 \%)$, high $(32 \%)$ and none (3\%). This result shows that they have reasonable knowledge of processing maize to pap. Knowledge of processing techniques in pop-corn: Low $(22 \%)$, average (45\%), high (24\%) and none 9\%. This result shows that they also have knowledge of processing maize to pop-corn. Knowledge of storage techniques in pap, agidi and pop-corn are high. Conduct of awareness programme on maize processing by extension workers: Low (17\%), average $(6 \%)$, high $(4 \%)$ and none $(73 \%)$. This result shows that there is no extension awareness programme. 
Table 4. Awareness to improved technology (Objective 3) (Rank rearrangement )

\begin{tabular}{|c|c|c|c|c|c|c|c|}
\hline $\mathrm{S} / \mathrm{N}$ & Items & A & SA & D & SD & Mean & Rank \\
\hline 1 & $\begin{array}{l}\text { Knowledge } \\
\text { processing maize into } \\
\text { pap }\end{array}$ & $32(32 \%)$ & $58(58 \%)$ & $7(7 \%)$ & $3(3 \%)$ & 3.19 & 1 \\
\hline 2 & $\begin{array}{l}\text { Knowledge } \\
\text { processing maize into } \\
\text { agidi }\end{array}$ & $28(28 \%)$ & $53(53 \%)$ & $16(16 \%)$ & $3(3 \%)$ & 3.06 & 2 \\
\hline 2 & $\begin{array}{l}\text { Level of awareness of } \\
\text { improved maize variety }\end{array}$ & $12(12 \%)$ & $63(63 \%)$ & $17(17 \%)$ & $8(8 \%)$ & 2.79 & 3 \\
\hline 3 & $\begin{array}{l}\text { Level of availability of } \\
\text { improve maize product }\end{array}$ & $14(14 \%)$ & $57(57 \%)$ & $22(22 \%)$ & $7(7 \%)$ & 2.78 & 4 \\
\hline 5 & $\begin{array}{l}\text { Knowledge of } \\
\text { processing maize into } \\
\text { pop corn }\end{array}$ & $24(24 \%)$ & $45(45 \%)$ & $22(22 \%)$ & $9(9 \%)$ & 2.84 & 5 \\
\hline 6 & $\begin{array}{l}\text { Modern storage } \\
\text { technique in pop corn }\end{array}$ & $9(9 \%)$ & $33(33 \%)$ & $30(30 \%)$ & $28(28 \%)$ & 2.63 & 6 \\
\hline 7 & $\begin{array}{l}\text { Modern storage } \\
\text { technique in pap }\end{array}$ & $13(13 \%)$ & $48(48 \%)$ & $22(22 \%)$ & $17(17 \%)$ & 2.57 & 7 \\
\hline 8 & $\begin{array}{l}\text { Modern storage in } \\
\text { agidi }\end{array}$ & $15(15 \%)$ & $44(44 \%)$ & $19(19 \%)$ & $22(22 \%)$ & 2.52 & 8 \\
\hline 9 & $\begin{array}{l}\text { How often do you get } \\
\text { access to modern } \\
\text { technology }\end{array}$ & $3(3 \%)$ & $28(28 \%)$ & $24(24 \%)$ & $45(45 \%)$ & 1.89 & 9 \\
\hline 10 & $\begin{array}{l}\text { Conduct of awareness } \\
\text { programme by } \\
\text { extension workers }\end{array}$ & $4(4 \%)$ & $6(6 \%)$ & $17(17 \%)$ & $73(73 \%)$ & 1.41 & 10 \\
\hline
\end{tabular}

Source: Field Survey, 2012

\subsection{Identifying the various products of maize in the area}

Results in Table 5 Showed the production of corn syrup: Yes (3\%) and No (97\%); Production of corn flakes in the area: Yes $(4 \%)$ and No $(96 \%)$; Production of corn oil: Yes (12\%), No (88\%); Production of corn sugar: Yes (15\%), No (85\%); Production of corn starch: Yes (30\%), No (70\%); Maize is not used as corn grits in the area, all the products former mentioned are not produced in the area. Yes (6\%) and No (94\%) Production of corn puddy: Yes (60\%), No (40\%), and Production of pap: Yes (98\%), No (2\%). This result shows that the area is highly involved in pap production which had the highest rank. Production of popcorn: Yes $(84 \%)$, No (16\%). Production of livestock feeds: Yes $(76 \%)$, No (24\%). This shows that maize and its residue are used for feeding livestock. Use of Maize as corn meal: Yes (72\%), No

(28\%). Production of Agidi and Agidi jollof: Yes (86\%) and No (14\%). The result 
shows that there is the production of agidi and agidi jollof in the area_ Maize can be eaten roasted, cooked or boiled: Yes (97\%), No (3\%). This shows that maize is highly used for consumption purposes in the area. Production of guguru in the area: Yas Yes (83\%), No $(17 \%)$. This shows that there is production of guguru in the area. Use of maize plant as medicinal purposes: Yes $(50 \%)$, no $(50 \%)$. The result shows that some of the fanners use maize plant for medicinal purposes and others do not.

Table 5. Identifying the various products of maize in the area (Objective 4) (Rank rearrangement )

\begin{tabular}{llcccccc}
\hline S/N & \multicolumn{1}{c}{ Items } & Yes & No & Yes & No & Mean & Rank \\
\hline 1 & Production of pap & 98 & 2 & 98 & 2 & 0.98 & 1 \\
2 & Eaten boiled, cooked roasted & 97 & 3 & 97 & 3 & 0.97 & 2 \\
3 & Production of Agidi and Agidi jollof & 86 & 14 & 86 & 14 & 0.86 & 3 \\
4 & Production of guguru & 83 & 17 & 83 & 17 & 0.83 & 4 \\
5 & Production livestock feeds & 76 & 24 & 76 & 24 & 0.76 & 5 \\
6 & Production of popcorn & 84 & 16 & 84 & 16 & 0.84 & 6 \\
7 & Production of corn meal & 72 & 28 & 72 & 28 & 0.72 & 7 \\
8 & Production of corn oil & 12 & 88 & 12 & 88 & 0.2 & 8 \\
9 & Production or corn puddy & 60 & 40 & 60 & 40 & 0.68 & 9 \\
10 & For medicinal purposes & 50 & 50 & 50 & 50 & 0.5 & 10 \\
11 & Production of corn sugar & 15 & 85 & 15 & 85 & 0.05 & 11 \\
12 & Production of corn grits & 6 & 94 & 6 & 94 & 0.06 & 12 \\
13 & Production of corn flakes & 4 & 96 & 4 & 96 & 0.04 & 13 \\
14 & Production of corn starch & 30 & 70 & 30 & 70 & 0.3 & 14 \\
15 & Production of corn syrup & 3 & 97 & 3 & 97 & 0.3 & 15 \\
\hline
\end{tabular}

Source: Field Survey, 2012

\subsection{Regression Analysis}

Ho: Socio-economic characteristics do not significantly affect maize processing.

From the estimated regression result for some socio economic characteristics did significantly affect processing. $\mathrm{R}^{2}$ value of 0.690 showed only $69 \%$ of the variation in quantity of raw maize processed is being explained by the independent variables. From the analysis of the age, quality of raw maize, household size and credit should produce relationship with the quantity of raw maize processed while processing methods shows no significant relationship with the dependent variable. However, household size has an inverse relationship with the dependent variable.

The table shows that the quantity of raw maize has an F-value of 7.81 and a probability value of 0.34 was significant at a critical level $(\mathrm{P} \leq 0.05)$. Thus, quantity of raw maize processed is significant in explaining the socio economic characteristics of female maize processors.

The result demonstrated that the some socio economic characteristics of female maize 
processors do not significantly affect productivity.

\subsection{Model Summary}

\begin{tabular}{|c|c|c|c|c|}
\hline Model & $\mathrm{R}$ & R Square & $\begin{array}{c}\text { Adjusted } \\
\text { R } \\
\text { Square }\end{array}$ & $\begin{array}{c}\text { Std. Error } \\
\text { of The Estimate }\end{array}$ \\
\hline 1 & $.702^{\mathrm{a}}$ & .690 & .713 & 1.51995 \\
\hline
\end{tabular}

\begin{tabular}{|c|c|c|c|c|c|}
\hline Model & $\begin{array}{c}\text { Sum of } \\
\text { square }\end{array}$ & Df & $\begin{array}{c}\text { Mean } \\
\text { square }\end{array}$ & F & Sig. \\
\hline Regression & 21.836 & 5 & 4.367 & 7.890 & $.034^{\mathrm{a}}$ \\
Residual & 217.164 & 94 & 2.310 & & \\
Total & 239.000 & 99 & & \\
\hline
\end{tabular}

\section{Summary, Conclusion and Recommendations}

The major objective of this work was to analyze maize processing. Female (91\%) were more into maize processing than male (9\%) in the study area. Ages between 31-40yrs were more active in maize processing, farmers with secondary education are more involved with maize processing, majority of the farmers are were married and were active maize farmers. Majority of the farmers used traditional processing methods and did not have access to credit facilities for processing, Most of the farmers were aware of improved maize varieties and products. Extension services were very poor in the area. The quantities of raw maize processed are up to average of grades and standard. Farmers did not often get access to modern technology and they had high knowledge of processing and storage techniques of local maize products.

For maize buyers, the quantity of maize bought is usually $100-150 \mathrm{~kg}$ (23\%) used for maize processing. Based on the findings, roles women play in maize processing is more than men.

\section{Conclusion}

Based on the findings of the study, the following conclusions are made. The result from the study showed that females are more into maize processing than male and they are within the ages of 31-40 years and are married. Most of the farmers are maize buyers rather than maize farmers. Traditional processing are mostly used, they don't have access to credit facilities for processing and the women are aware of improve maize varieties. Extension services are minimal in the area. Production of pap, pop corn, guguru, agidi, and use of maize for livestock feed is rampant in the area. Socio-economic characteristics did affect productivity in maize processing such as age, quantity of raw maize processed, house-bold size, processing methods. 


\section{Recommendations}

a) Males should be encouraged to go into maize processing and should not be regarded as females' jobs.

b) All age categories and farmers with no formal education should be encouraged to go into maize processing.

c) More awareness should be brought to farmers processors on improved varieties.

d) Credit facilities should be made available to maize processors.

e) Singles should be encouraged to go into maize processing.

f) Modern processing techniques should be introduced in the area.

g) 7 Maize processors should be coopted into cooperative formation.

\section{References}

Ajibefun, I. A. Battle, G. E., \& Daramola, E. A. (2002): Determinants of technical efficiency in small holder cropping farming in Oyo State Nigeria. Quarterly Journal of International Agriculture. Journal of International Agriculture, 41(3), 225-240.

Anyanwu, A. C. Anyanwu B. O., \& Anyanwu V.A. (1999). A text book of agricultural science for schools and colleagues fifth edition. Africana-feb publishers limited.

Eboh, E. C., Okoye, C. U., \& Ayichi, D. (1995) Rural finance credit and insurance in rural development in Nigeria concept, process and prospects. Auto century publishing company, Enugu.

Ingawa, S. A. (1999) Welcome Address at the National Workshop for Women in Agriculture, held in FACU Headquarter, Sheda Abuja, Nigeria $31^{\text {st }}$ August $-2^{\text {nd }}$ September.

Kabeer, N. (1987) Reversed Realities, Gender Hierachies in Development Thought. Verso, London, UK Lanjouw, J. O., \& P. Lanjouw 2001. The rural non-farm sector: Issus and evidence from developing countries. World Development, 26, 1-23.

Malena (1994) Gender issues in integrated pest management in African Agriculture NRI Socio economic series. 5.Natural Resources Institute Chatham, UK.

Mgbada, J. U. (2000) Production of stable crop by rural women in Enugu and Ebonyi states: Lesson for enhancing poverty alleviation programmes. In: Olowu, T. A. (ed) Agricultural extension and poverty alleviation in Nigeria. Proceedings of the $6^{\text {th }}$ National Conference of the Agricultural Extension Society, 10-12.

Ngur, N. (1987) Women and development in crop and livestock production in Northern Nigeria: What changes? Paper Presentation at the Seminar on women's studies at Women's Research and documentation centre, Institute of African Studies, University of Ibadan, November.

Ojo (2000). factor productivity in maize production in Ondo State Nigeria. Applied Tropical 
Agriculture.

Osagie, A. U. ad Eka D.U. (1998). Nutritional Quality foods. In Abdulrahaman, A, A, and O.M. Kolawole: Traditional preparations ad use of maize in Nigeria. Retrieved from: http://www.siu.edu/ebi/leaflets/kolawole.html on 15th March, 2008.

Purseglove, J. W. (1992). "Tropical Crops" monocotyledons. In Abdulrahaman, A. A. and O.M. Kolawole, Traditional preparations and uses of maize in Nigeria. Retrieved from: http://www.siu.edu/ebi/leaflets/kolawole.html on 15th March, 2008.

Whatmore, S. (1991). Women in Agriculture”, Journal of Rural Studies, 7(1/2) Special Issue.

\section{Copyright Disclaimer}

Copyright for this article is retained by the author(s), with first publication rights granted to the journal.

This is an open-access article distributed under the terms and conditions of the Creative Commons Attribution license (http://creativecommons.org/licenses/by/3.0/). 